\title{
X-ray absorption evidence for a new type of niobium mineralisation in laterites
}

\author{
QUENTIN BOLLAERT ${ }^{1}$, MATHIEU CHASSÉ ${ }^{1}$, CÉCILE \\ QUANTIN $^{2}$, ALEXANDRA COURTIN-NOMADE ${ }^{3}$, \\ LAURENCE GALOISY $^{1}$ AND GEORGES CALAS ${ }^{1}$ \\ ${ }^{1}$ Sorbonne Université \\ ${ }^{2}$ GEOPS, Université Paris-Saclay, CNRS \\ ${ }^{3}$ Université Paris-Saclay - CNRS \\ Presenting Author: quentin.bollaert@sorbonne-universite.fr
}

Niobium $(\mathrm{Nb})$ is a critical element with a wide range of technological applications for which Brazil has a near-monopoly on world supply [1]. Brazilian lateritic deposits are considered to be formed by in situ accumulation of resistant niobium host minerals such as pyrochlore and columbite under intense supergene weathering of primary magmatic rocks enriched in niobium. Nonetheless, evidence of such resistance during lateritic alteration are lacking and the contribution of other niobium host minerals remains to be determined.

The study of the Madeira lateritic deposit (Amazonas, Brazil) combining bulk mineralogy and geochemistry, chemical mapping and X-ray absorption near-edge structure (XANES) spectroscopy highlights the alteration of primary $\mathrm{Nb}$-bearing minerals and the occurrence of $\mathrm{Nb}$-enriched $\mathrm{Fe}$ and $\mathrm{Ti}$ oxides in the laterite. Along the weathering profile, $\mathrm{Nb}$ is hosted by columbite, hematite and anatase. The alteration of columbite in the most weathered horizons releases $\mathrm{Nb}$ that incorporates into neoformed hematite and anatase accounting for the total niobium bulk content ( $c a 800 \mathrm{ppm}$ ).

The comparison with various Nb-rich laterites worldwide shows that a single model cannot explain the formation of niobium deposits. We propose a second model in which $\mathrm{Nb}$ is trapped by secondary oxides after the weathering of primary $\mathrm{Nb}$ bearing minerals. The world largest $\mathrm{Nb}$ deposit, (Morro Dos Seis Lagos) exhibits $\mathrm{Nb}$-enriched $\mathrm{Fe}$ and $\mathrm{Ti}$ oxides [2] and may thus be formed through similar processes.

In this context of uncertainty of supply sources and commitment to reduce and reuse mining wastes, our detailed characterization of $\mathrm{Nb}$ ore minerals with XANES techniques will help to improve ore processing in order to enhance $\mathrm{Nb}$ recovery from active mines [3] and develop recovery from scrap and waste materials [4].

[1] European Commission (2020), Study on the EU's list of Critical Raw Materials - Final Report. [2] Giovannini et al. (2017), Ore Geology Reviews 88, 461-480. [3] Černý and Ercit (1989), Lanthanides, Tantalum and Niobium. Society for Geology Applied to Mineral Deposits, vol 7. [4] SanchezSeguado et al. (2017) Scientific Reports, 7:18016. 